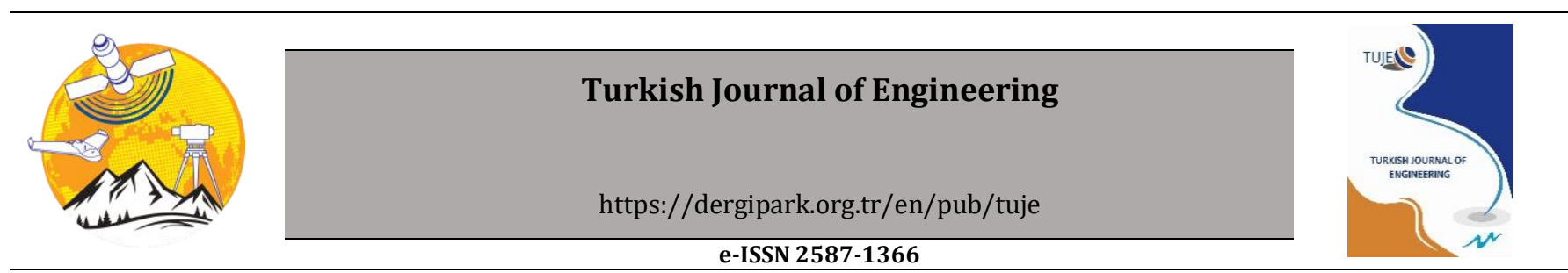

\title{
An experimental study of the performance of a low-cost paper-based membraneless direct hydrogen peroxide fuel cell
}

\author{
Muhammet ÇELIK *1) \\ ${ }_{1}^{1}$ Aksaray University, Engineering Faculty, Department of Mechanical Engineering, Aksaray, Turkey
}

\author{
Keywords \\ Hydrogen Peroxide Fuel \\ Cell \\ DHPFC \\ Fuel Cell Performance \\ Membraneless Fuel Cell \\ Paper-based Fuel Cell
}

\begin{abstract}
A paper-based membraneless direct hydrogen peroxide fuel cell was developed and tested under different potassium hydroxide concentrations ( 1 to $7 \mathrm{~mol} \mathrm{lt}^{-1}$, stepping by 2), different hydrogen peroxide concentrations $\left(1,2,3 \mathrm{~mol} \mathrm{lt}^{-1}\right)$ and different temperatures $\left(20,30,40{ }^{\circ} \mathrm{C}\right)$. Moreover, the developed fuel cell was studied for stability under stopped and continuous flow conditions. From the experiments, it was found that the maximum power density of $6.79 \mathrm{~mW}$ $\mathrm{cm}^{-2}$ and the maximum open circuit voltage of $0.87 \mathrm{~V}$ at $40^{\circ} \mathrm{C}$ were obtained when the anode solution consisted $2 \mathrm{~mol} \mathrm{lt}^{-1} \mathrm{H}_{2} \mathrm{O}_{2}$ and $5 \mathrm{~mol} \mathrm{lt}^{-1}$ potassium hydroxide and cathode solution consisted $2 \mathrm{~mol} \mathrm{lt}^{-1}$ sulfuric acid and $2 \mathrm{~mol} \mathrm{lt}^{-1}$ hydrogen peroxide. It was found that if the reactants were supplied constantly into the fuel cell, a current density of $3.12 \mathrm{~mA} \mathrm{~cm}-2$ was obtained. The developed fuel cell produced energy for 91 minutes when the reactant flow was stopped.
\end{abstract}

\section{INTRODUCTION}

Membraneless fuel cells (FC) have obtained attention by researchers in recent years due to their simple structure, low cost, and low environmental impact properties. The absence of a membrane in these fuel cells provides some advantages such as avoiding membrane degradation, providing low cost and low internal resistance. Because of the simplicity of membraneless FCs, they can be used to generate power for biological sample analysis (Esquivel et al. 2014), wearable electronics (Valdés-Ramirez et al. 2014, Bandodkar et al. 2015), and supercapacitors (Lu et al. 2014). Moreover, this type of FCs has a wide range of applicability due to the fact that they can produce energy using various solutions such as methanol (Zhang et al. 2019), glucose (Shitanda et al. 2017, Gonzalez-Guerrero et al. 2017), vanadium (Jung and Ahn 2020), human blood (Dector et al. 2017), urea (Chino et al. 2018), formic acid (Copenhaver et al. 2015), hydrogen peroxide (Yang et al. 2019, Ehteshami et al. 2016, Yan et al. 2018), etc. Within this variety of fuels, hydrogen peroxide $\left(\mathrm{H}_{2} \mathrm{O}_{2}\right)$ is an attractive fuel because: I) it has a carbon-free structure,
II) it can be obtained via using renewable energy sources such as solar energy (Yamada et al. 2010), it can be used both the oxidant and the fuel at the same time in an FC (Yamazaki et al. 2008).

In recent years, employing paper in membraneless FCs has become interesting since the fluids are driven by the capillary effect on the paper. Therefore, any pump for the reactant supplement into the cell is not needed in these FCs. Furthermore, the paper is abundant, lightweight, recyclable, and low-cost material. Arun et al. (2014) developed a formic acid FC which had graphite electrodes stroked with pencil on the paper. The developed $\mathrm{FC}$ reached $32 \mathrm{~mW} \mathrm{~cm}^{-2}$ maximum power density (MPD) and $650 \mathrm{~mA} \mathrm{~cm}^{-2}$ maximum current density (MCD). Jung and Ahn (2020) investigated a paper-based vanadium FC consisted of graphene paste electrodes. The FC produced $15.09 \mathrm{~mW} \mathrm{~cm}^{-2} \mathrm{MPD}$ and 30 $\mathrm{mA} \mathrm{cm}^{-2}$ MCD. Shen et al. (2019) built up a paper-based FC that utilizes $\mathrm{KCOOH}$ as fuel and air as the oxidant. They tested some operating parameters influences such as textural properties of paper, fuel crossover, or cell resistance. The MPD of $7.10 \mathrm{~mW} \mathrm{~cm}^{-2}$ and the maximum OCV of $0.86 \mathrm{~V}$ were acquired from the FC. Zhang et al. 
(2012) demonstrated a biofuel cell on paper that produces energy from some beverages directly. The study showed that the cell could be used as a portable energy provider. Dector et al. (2017) reported paperbased FC that supplies energy for HIV test. The study is so important as it proved that the paper-based FCs could be applied to provide energy from human blood for point-of-care testing.

Studies that use hydrogen peroxide as the fuel or the oxidant inside the FC have been performed by Yang et al. (2019), Ehteshami et al. (2016), Shyu et al. (2012), Han et al. (2015), Shaegh et al. (2014) and Yang et al. (2012). A paper-based hydrogen peroxide FC that utilizes hydrogen peroxide as both the oxidant and the fuel was introduced by Yan et al. (2018). The FC achieved an MPD of $0.88 \mathrm{~mW} \mathrm{~cm}^{-2}$. The study showed that the hydrogen peroxide can be useable as a sustainable energy carrier. Ehteshami et al. (2016) reported a paper-based FC prepared by micro-fabrication that utilizes hydrogen peroxide both the oxidant and the fuel. The prepared FC produced $0.81 \mathrm{~mW} \mathrm{~cm}^{-2}$ for aluminum anode whereas it produced $0.38 \mathrm{~mW} \mathrm{~cm}^{-2}$ power for nickel anode. By a closer look to the literature, there is a lack of study that emphasizes the economy for the paper-based hydrogen peroxide fuel cell.

Herein, a low-cost, Y-shaped, paper-based direct hydrogen peroxide fuel cell (DHPFC) which uses the hydrogen peroxide as fuel in the alkaline medium and the oxidant in the acidic medium was developed and its performance was investigated. In order to analyze the performance, the voltage-current measurements at different $\mathrm{KOH}$ concentrations (1, 3, 5, $\left.7 \mathrm{~mol} \mathrm{lt}^{-1}\right)$, different $\mathrm{H}_{2} \mathrm{O}_{2}$ concentrations $\left(1,2,3 \mathrm{~mol} \mathrm{lt}^{-1}\right)$ and different temperatures $\left(20,30,40^{\circ} \mathrm{C}\right)$ were carried out. Moreover, to investigate the stability of the DHPFC chronoamperometry tests under two conditions (continuous flow and stopped flow) were examined.

\section{METHOD}

A DHPFC is one type of fuel cells that generates electricity from hydrogen peroxide directly. Due to the nature of the hydrogen peroxide, it can be used as the oxidant and the reductant at the same time in a fuel cell. In an acidic medium, the hydrogen peroxide plays a role as oxidant and generates electrons. In an alkaline medium, it serves as a reductant and accepts the electrons. (Hasegawa et al. 2004) Because of this behavior, the hydrogen peroxide becomes usable in the fuel cells. The reactions that occurred in a direct hydrogen peroxide fuel cell (DHPFC) concerning the anode and the cathode are as follows (Ye et al. 2015):

$$
\begin{array}{ll}
\text { Anode: } \mathrm{H}_{2} \mathrm{O}_{2}+2 \mathrm{OH}^{-} \rightarrow \mathrm{O}_{2}+\mathrm{H}_{2} \mathrm{O}+2 \mathrm{e}^{-} & \text {E: } 0.146 \mathrm{~V} \\
\text { Cathode: } \mathrm{H}_{2} \mathrm{O}_{2}+2 \mathrm{H}^{+}+2 \mathrm{e}^{-} \rightarrow 2 \mathrm{H}_{2} \mathrm{O} & \text { E: } 1.776 \mathrm{~V} \\
\text { Overall: } 2 \mathrm{H}_{2} \mathrm{O}_{2} \rightarrow \mathrm{O}_{2}+2 \mathrm{H}_{2} \mathrm{O} & \text { E: } 1.630 \mathrm{~V}
\end{array}
$$

With this knowledge, the alkaline medium was provided in the anode by making a solution of $\mathrm{H}_{2} \mathrm{O}_{2}$ and $\mathrm{KOH}$. On the other hand, the acidic medium was provided in the cathode by making a solution of $\mathrm{H}_{2} \mathrm{O}_{2}$ and $\mathrm{H}_{2} \mathrm{SO}_{4}$. The main reason of being the high cost of an FC is the catalyst material and membrane costs. Here, an economic point of view was adopted. Therefore, the
DHPFC was considered membraneless for the purpose of eluding membrane cost and energy requirement for pumping reactants. For a paper-based fuel cell, the working principle can be listed as follows:

i) Anode and cathode solutions transport into the fuel cell by capillary action through the flow channels.

ii) The solutions reach the mixing region. The anode and the cathode solution streams meet with each other firmly (diffusion zone in Fig. 1) since the flow of the solutions is in laminar because of the capillary action. Due to the stable streams of the solutions, the demand for separation of membrane disappears (Hasegawa et al. 2004).

iii) The electricity is produced by the anode and the cathode reactions via transporting the electrons from the anode to the cathode with an external circuit. In order to increase the reactions, the appropriate catalyst material is used for the anode and the cathode.

In this work, as the catalyst material, while cheap and abundant nickel was used for the anode electrode, carbon was used for the cathode electrode. All these attempts to reduce the cost will cause an adverse effect on the cell performance. For this reason, the developed DHPFC can be considered to provide power for lowpower applications such as medical diagnostic sensors, wearable electronic devices, or drug pumps.

Whatman filter paper (Grade 3) was used as the platform for fluid streams by capillary action. As can be seen from the Fig.1, the paper was cut Y-shape which had $40 \mathrm{~mm}$ channel length and $10 \mathrm{~mm}$ channel width. Anode and cathode reactants reservoirs were attached to the flow channels. Anode solution $\left(\mathrm{H}_{2} \mathrm{O}_{2}+\mathrm{KOH}\right)$ and cathode solution $\left(\mathrm{H}_{2} \mathrm{O}_{2}+\mathrm{H}_{2} \mathrm{SO}_{4}\right)$ were transported via capillary effect from the reservoirs to the channels first and then the mixture region which was $40 \mathrm{~mm}$ in length and 20 $\mathrm{mm}$ in width.

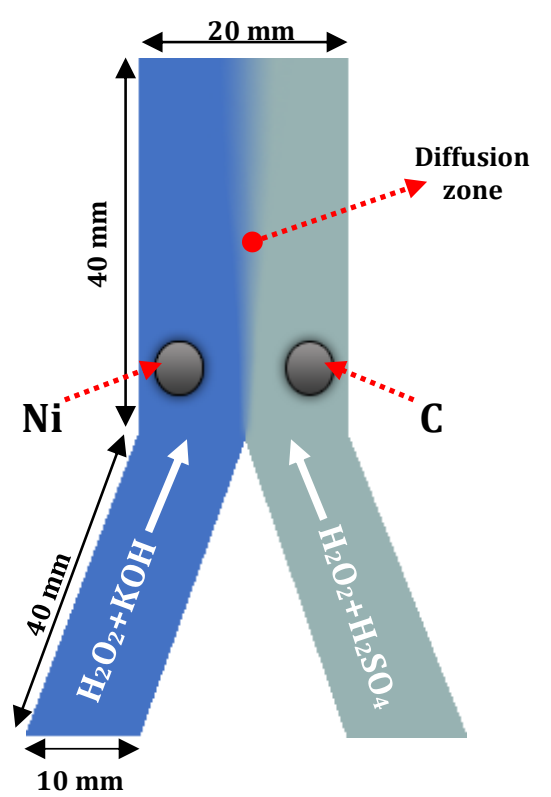

Figure 1. Schematic illustration of the DHPFC.

Catalyst inks were prepared with \%4 sol. polyvinyl alcohol (PVA) (0.139 g), water (2.23g), and catalyst $(0.947 \mathrm{~g})$. PVA was chosen as the catalyst binder instead of a highly expensive Nafion solution. Prepared catalyst 
inks ( $\sim 13 \mathrm{mg}$ ) were directly painted on the paper to form a $4 \mathrm{~mm}$ diameter circle. After painting and drying the catalyst inks, a steel mesh was attached to each electrode by alligator clips.

The voltage-current and chronoamperometry measurements were taken by using a DC electronic load (Maynuo M9711). Voltage-current measurements were taken with 3-second intervals at 15 steps from the opencircuit voltage (OCV) after the reactants reached the mixing region and OCV was stabilized. According to obtained results from the measurements, power density curves (marked with dashed lines with respect to right yaxis) and polarization curves (marked with solid lines with respect to left y-axis) were created and plotted in the same graph. Constant voltage measurements were taken under two different conditions. Firstly, the current density was measured at $0.4 \mathrm{~V}$ constant voltage under continuous flow of reactants. After that, the reactants were removed from the DHPFC and the current density was measured at the same constant voltage value. The experiments were carried out at $20^{\circ} \mathrm{C}$ unless otherwise stated in the manuscript. In order to make sure the experiment results were accurate; all the experiments were carried out at least 3 times.

\section{RESULTS}

\subsection{Effect of $\mathrm{KOH}$ Concentration}

In the anode, the $\mathrm{OH}^{-}$ions in the $\mathrm{KOH}$ react with the $\mathrm{H}_{2} \mathrm{O}_{2}$ with a stoichiometric ratio which dissociates the $\mathrm{H}_{2} \mathrm{O}_{2}$ and exposes electrons, as given in Eq.1. Besides the other significant role of the $\mathrm{KOH}$ in the DHPFC, it serves as the supporting electrolyte by carrying the $\mathrm{H}_{2} \mathrm{O}_{2}$ into the electrochemical active site. Nevertheless, the $\mathrm{KOH}$ concentration should be optimized in the anode solution. At the excess concentrations, the $\mathrm{KOH}$ affects the cell performance negatively. Because the viscosity of the anode solution rises at the $\mathrm{KOH}$ concentrations (Guo et al. 2016), and the transportation of the $\mathrm{H}_{2} \mathrm{O}_{2}$ can be limited by the blockage of the $\mathrm{OH}^{-}$ions in the active sites (Rathoure and Pramanik, 2016). With this consideration, the $\mathrm{H}_{2} \mathrm{O}_{2}$ concentration was fixed at $2 \mathrm{~mol} \mathrm{lt}^{-1}$ in anode solution, whereas the $\mathrm{KOH}$ concentration was varied from 1 to $7 \mathrm{~mol} \mathrm{lt}^{-1}$. As can be seen from the Fig. 2, the performance of the DHPFC was increased by the $\mathrm{KOH}$ concentration increment up to $5 \mathrm{~mol} \mathrm{lt}^{-1}$. When the concentration of $\mathrm{KOH}$ at $7 \mathrm{~mol} \mathrm{lt}^{-1}$, the performance significantly dropped. As discussed, the reason for the performance drop was the diffusion losses. The maximum OCV was $0.84 \mathrm{~V}$ and the MPD was $5.3 \mathrm{~mW} \mathrm{~cm}^{-}$ 2 at $5 \mathrm{~mol} \mathrm{lt}^{-1} \mathrm{KOH}$ concentration. The lowest current density (LCD) of $6.56 \mathrm{~mA} \mathrm{~cm}^{-2}$ at $1 \mathrm{~mol} \mathrm{lt}^{-1} \mathrm{KOH}$ and the highest current density (HCD) of $27.36 \mathrm{~mA} \mathrm{~cm}^{-2}$ were found at $5 \mathrm{~mol} \mathrm{lt}^{-1} \mathrm{KOH}$.

\subsection{Effect of $\mathrm{H}_{2} \mathrm{O}_{2}$ Concentration}

Fig. 3 shows the impact of $\mathrm{H}_{2} \mathrm{O}_{2}$ in the anode solution on the DHPFC performance. The $\mathrm{KOH}$ concentration in the anode solution was kept constant at $5 \mathrm{~mol} \mathrm{lt}^{-1}$ and the $\mathrm{H}_{2} \mathrm{O}_{2}$ concentration changed from 1 to $3 \mathrm{~mol} \mathrm{lt}^{-1}$. It was found that from the experiments, the MPD was $5.31 \mathrm{~mW}$ $\mathrm{cm}^{-2}$ and the $\mathrm{OCV}$ was $0.84 \mathrm{~V}$ when the $\mathrm{H}_{2} \mathrm{O}_{2}$ concentration was $2 \mathrm{~mol} \mathrm{lt}^{-1}$. The LCD of $18.16 \mathrm{~mA} \mathrm{~cm}^{-2}$ at $1 \mathrm{~mol} \mathrm{lt}^{-1}$ and the HCD of $27.36 \mathrm{~mA} \mathrm{~cm}^{-2}$ at $2 \mathrm{~mol} \mathrm{lt}^{-1}$ were measured. It was observed that the OCV was not strongly dependent on the $\mathrm{H}_{2} \mathrm{O}_{2}$ concentration in the anode solution. The DHPFC performance increased by increasing the concentration of $\mathrm{H}_{2} \mathrm{O}_{2}$ from 1 to $2 \mathrm{~mol} \mathrm{lt}^{-1}$. After the $2 \mathrm{~mol} \mathrm{lt}^{-1} \mathrm{H}_{2} \mathrm{O}_{2}$ concentration, the DHPFC performance was affected negatively. This adverse effect in the performance may be related to the limitation of $\mathrm{H}_{2} \mathrm{O}_{2}$ transport to the electrocatalytic active site by $\mathrm{O}_{2}$ molecules generated from the $\mathrm{H}_{2} \mathrm{O}_{2}$ dissociation (Shyu et al. 2012, Yang et al. 2012), as expressed in Eq.2. The MPDs were obtained as $2.82 \mathrm{~mW} \mathrm{~cm}^{-2}$ at $1 \mathrm{~mol} \mathrm{lt}^{-1} \mathrm{H}_{2} \mathrm{O}_{2}$, $5.31 \mathrm{~mW} \mathrm{~cm}^{-2}$ at $2 \mathrm{~mol} \mathrm{lt}^{-1} \mathrm{H}_{2} \mathrm{O}_{2}$ and $3.06 \mathrm{~mW} \mathrm{~cm}^{-2}$ at 3 mol lt-1 $\mathrm{H}_{2} \mathrm{O}_{2}$, respectively.

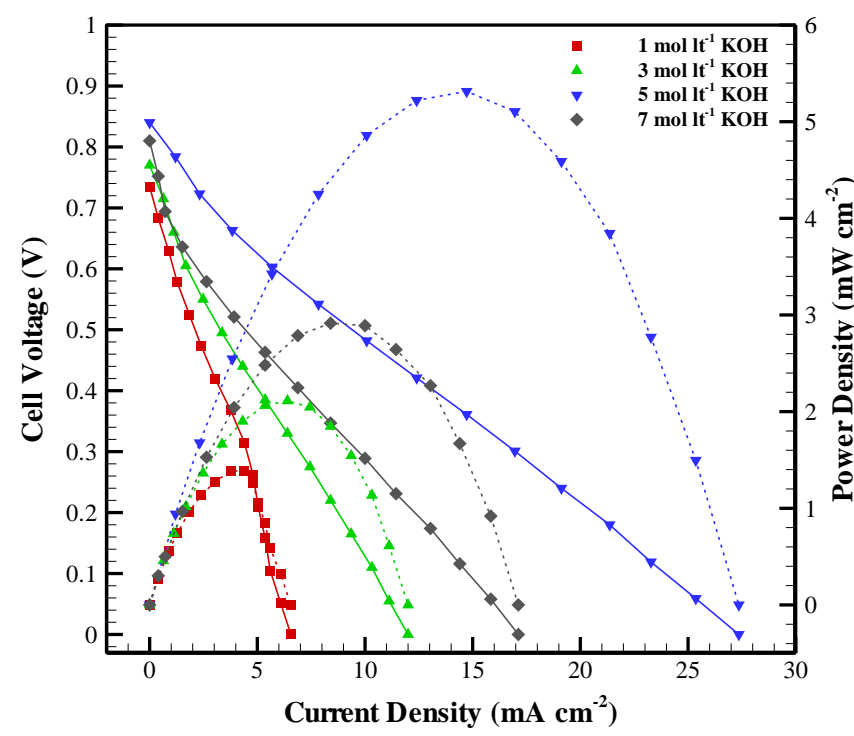

Figure 2. The impact of $\mathrm{KOH}$ concentration on the DHPFC performance

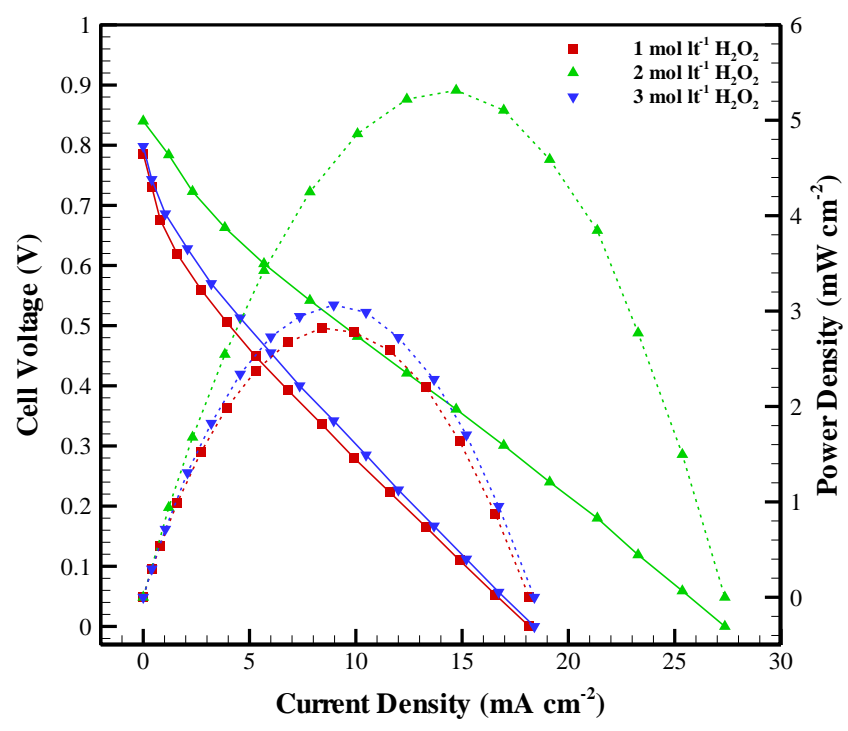

Figure 3. The influence of $\mathrm{H}_{2} \mathrm{O}_{2}$ concentration on the DHPFC performance

\subsection{Effect of Operating Temperature}

Fig 4. depicts the polarization curve according to operating temperature. The operating temperature was changed from $20^{\circ} \mathrm{C}$ to $40^{\circ} \mathrm{C}$ in order to determine the 
effect of the temperature on the DHPFC performance. The OCVs were $0.84 \mathrm{~V}, 0.86 \mathrm{~V}$ and $0.87 \mathrm{~V}$ at $20^{\circ} \mathrm{C}, 30^{\circ} \mathrm{C}$ and $40^{\circ} \mathrm{C}$, respectively. As can be seen from the Fig. 4 , especially at the ohmic and diffusion overvoltage regions, graphs were escalated with the operating temperature. The reason for this is the electrical conductivity increases as the temperature rises which results the ohmic overpotential drop. Moreover, the diffusion overvoltage occurs when the reactants yielded at the electrochemical active sites. When the temperature rises, the diffusion of the reactants increases. So, the diffusion losses reduce. Consequently, these declines of the ohmic and the diffusion overpotentials conduce to an increase of the DHPFC performance. The experimental results can be given as the MPD was $5.29 \mathrm{~mW} \mathrm{~cm}^{-2}$ at $20^{\circ} \mathrm{C}$ while it was $6.79 \mathrm{~mW} \mathrm{~cm}^{-2}$ at $40^{\circ} \mathrm{C}$. While the LCD was $27.36 \mathrm{~mA} \mathrm{~cm}^{-}$ 2 at $20^{\circ} \mathrm{C}$, the $\mathrm{HCD}$ was $33.84 \mathrm{~mA} \mathrm{~cm}^{-2}$ at $40^{\circ} \mathrm{C}$.

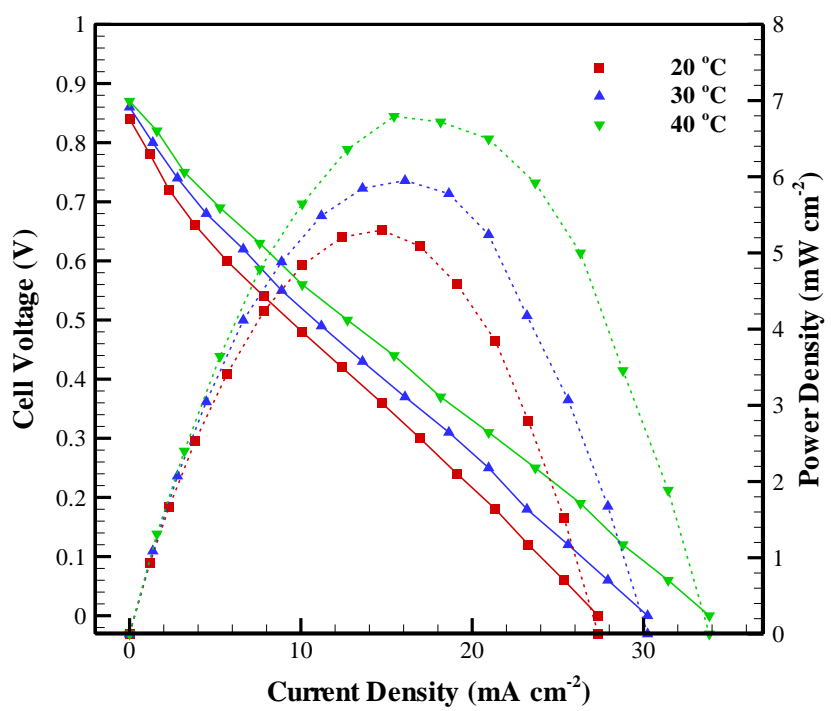

Figure 4. The impact of temperature on the DHPFC performance

\subsection{Chronoamperometry Tests}

Chronoamperometry tests were carried out to analyze the stability of the developed DHPFC. Tests were examined in two cases: 1) continuous flow condition, 2) stopped flow condition.

Continuous flow condition experiments were carried out when the reactants reached the mixing region, the DHPFC completely saturated with reactants and the OCV was stabilized. While the anode solution was 2 mol lt $^{-1}$ $\mathrm{H}_{2} \mathrm{O}_{2}+5 \mathrm{~mol} \mathrm{lt}^{-1} \mathrm{KOH}$, the cathode solution was $2 \mathrm{~mol} \mathrm{lt}^{-1}$ $\mathrm{H}_{2} \mathrm{O}_{2}+2$ mol lt $\mathrm{t}^{-1} \mathrm{H}_{2} \mathrm{SO}_{4}$. The voltage of the DHPFC was fixed at $0.4 \mathrm{~V}$ during the experiment. The experiments were carried out under these conditions for $50 \mathrm{~min}$. (3000 seconds).

As can be seen from the Fig. 5, under continuous flow condition, the current density was stabilized near 3.12 $\mathrm{mA} \mathrm{cm}^{-2}$ of current density. In addition, $1.25 \mathrm{~mW} \mathrm{~cm}^{-2}$ of power density was acquired. Stopped flow condition experiments were carried out by detaching the reactants reservoir from the DHPFC flow channels. The cell voltage was the same as the continuous flow condition. Under the stopped flow condition, the current density dropped from 8.08 to $0.64 \mathrm{~mA} \mathrm{~cm}^{-2}$ until the end of $50 \mathrm{~min}$. After
91 minutes, the reactants in the electrochemical active site were depleted. As a result of this, the current density acquired from the DHPFC dropped to zero.

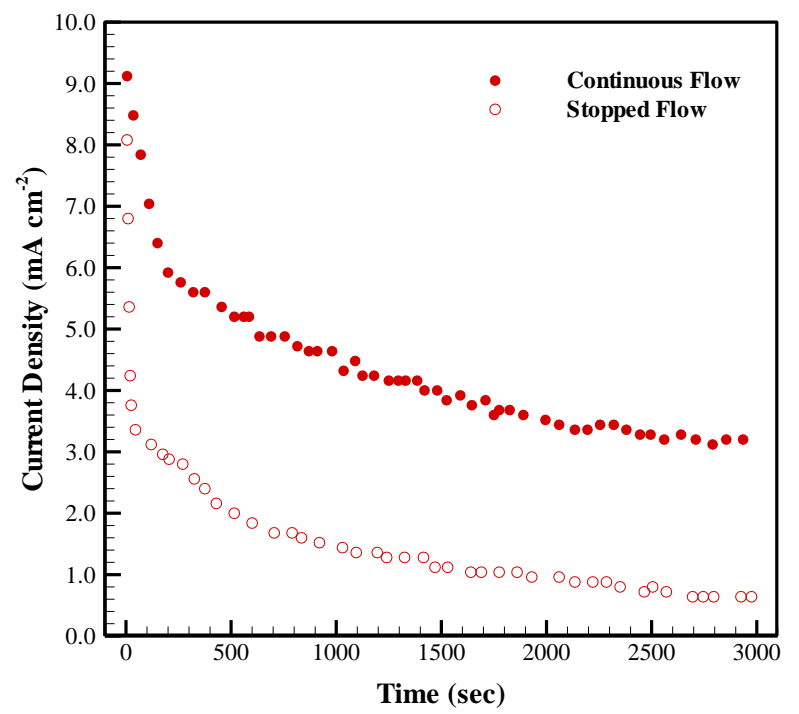

Figure 5. Chronoamperometry tests

\section{CONCLUSION}

A paper-based membraneless DHPFC was developed and tested in this study. In order to develop a low-cost FC, the nickel for the anode and the carbon powder for the cathode were chosen as catalysts, respectively. As the catalyst binder, PVA was used instead of a highly expensive Nafion binder. The DHPFC was tested for different anode solution compositions and different temperatures. Furthermore, to specify the stability of the developed DHPFC, chronoamperometry tests were examined. The followings can be concluded from the experiments:

- $\quad$ Among all the experiments, the MPD of $6.79 \mathrm{~mW}$ $\mathrm{cm}^{-2}$ and the maximum OCV of $0.87 \mathrm{~V}$ at $40^{\circ} \mathrm{C}$ is obtained when the anode solution consisted 2 mol lt$^{-1} \mathrm{H}_{2} \mathrm{O}_{2}+5$ mol lt $^{-1} \mathrm{KOH}$ with the cathode solution consisted $2 \mathrm{~mol} \mathrm{lt}^{-1}$ $\mathrm{H}_{2} \mathrm{O}_{2}+2 \mathrm{~mol} \mathrm{lt}^{-1} \mathrm{H}_{2} \mathrm{SO}_{4}$. With the same anode solution and cathode solution components, the DHPFC produces a power density of $5.3 \mathrm{~mW} \mathrm{~cm}^{-2}$ and reached $0.84 \mathrm{~V}$ at $20^{\circ} \mathrm{C}$.

- The developed DHPFC is tested for stability under stopped and continuous flow conditions. It is seen that if the reactants flowed constantly into the DHPFC, a $3.12 \mathrm{~mA} \mathrm{~cm}^{-2}$ current density and $1.25 \mathrm{~mW} \mathrm{~cm}^{-2}$ power density were obtained.

- When the reactant flow to the cell was stopped, the DHPFC produces energy (although it diminishes) for $91 \mathrm{~min}$.

Consequently, the findings of this study bring out that the paper-based DHPFC could be built at a low-cost and it could be used to provide power for small power requirements.

\section{Conflicts of interest}

The authors declare no conflicts of interest.

\section{REFERENCES}

Arun R K, Halder S, Chanda N \& Chakraborty S (2014). A paper based self-pumping and self-breathing fuel cell 
using pencil stroked graphite electrodes. Lab on a Chip, 14(10), 1661-1664.

Bandodkar A J, Jia W, Wang J (2015). Tattoo-Based Wearable Electrochemical Devices: A Review. Electroanalysis. 27, 562-572.

Chino I, Muneeb O, Do E, Ho V \& Haan J L (2018). A paper microfluidic fuel cell powered by urea. Journal of Power Sources, 396, 710-714.

Copenhaver T S, Purohit K H, Domalaon K, Pham L, Burgess B J, Manorothkul N, ... \& Haan J L (2015). A microfluidic direct formate fuel cell on paper. Electrophoresis, 36(16), 1825-1829.

Dector A, Galindo-De-La-Rosa J, Amaya-Cruz D M, OrtízVerdín A, Guerra-Balcázar M, Olivares-Ramírez J M, ... \& Ledesma-García J (2017). Towards autonomous lateral flow assays: Paper-based microfluidic fuel cell inside an HIV-test using a blood sample as fuel. International Journal of Hydrogen Energy, 42(46), 27979-27986.

Ehteshami S M M, Asadnia M, Tan S N \& Chan S H (2016). Paper-based membraneless hydrogen peroxide fuel cell prepared by micro-fabrication. Journal of Power Sources, 301, 392-395.

Esquivel J P, Del Campo F J, De La Fuente J G, Rojas S \& Sabate N (2014). Microfluidic fuel cells on paper: meeting the power needs of next generation lateral flow devices. Energy \& Environmental Science, 7(5), 1744-1749.

González-Guerrero M J, Del Campo F J, Esquivel J P, Leech D \& Sabaté N (2017). based microfluidic biofuel cell operating under glucose concentrations within physiological range. Biosensors and Bioelectronics, 90, 475-480.

Guo F, Cao D, Du M, Ye K, Wang G, Zhang W, ... \& Cheng K (2016). Enhancement of direct urea-hydrogen peroxide fuel cell performance by three-dimensional porous nickel-cobalt anode. Journal of Power Sources, 307, 697-704.

Hasegawa S, Shimotani K, Kishi K \& Watanabe H (2004). Electricity generation from decomposition of hydrogen peroxide. Electrochemical and Solid State Letters, 8(2), A119.

Han L, Guo S, Wang P \& Dong S (2015). Light-Driven, Membraneless, Hydrogen Peroxide Based Fuel Cells. Advanced Energy Materials, 5(2), 1400424.

Jung D G \& Ahn Y (2020). Microfabricated paper-based vanadium co-laminar flow fuel cell. Journal of Power Sources, 451, 227801.

Lu X, Yu M, Wang G, Tong Y \& Li Y (2014). Flexible solidstate supercapacitors: design, fabrication and applications. Energy \& Environmental Science, 7(7), 2160-2181.

Rathoure A K \& Pramanik H (2016). Electrooxidation study of methanol using $\mathrm{H} 2 \mathrm{O} 2$ and air as mixed oxidant at cathode in air breathing microfluidic fuel cell. International Journal of Hydrogen Energy, 41(34), 15287-15294.

Shaegh S A M, Ehteshami S M M, Chan S H, Nguyen N T \& Tan S N (2014). Membraneless hydrogen peroxide micro semi-fuel cell for portable applications. RSC advances, 4(70), 37284-37287.

Shen L L, Zhang G R, Venter T, Biesalski M \& Etzold B J (2019). Towards best practices for improving paperbased microfluidic fuel cells. Electrochimica Acta, 298, 389-399.

Shitanda I, Nohara S, Hoshi Y, Itagaki M \& Tsujimura S (2017). A screen-printed circular-type paper-based glucose/02 biofuel cell. Journal of Power Sources, 360, 516-519.

Shyu J C, Huang C L, Sheu T S \& Ay H (2012). Experimental study of direct hydrogen peroxide microfluidic fuel cells. Micro \& Nano Letters, 7(8), 740-743.

Valdés-Ramírez G, Li Y C, Kim J, Jia W, Bandodkar A J, Nuñez-Flores R, ... \& Wang J (2014). Microneedlebased self-powered glucose sensor. Electrochemistry Communications, 47, 58-62.

Yamada Y, Fukunishi Y, Yamazaki S I \& Fukuzumi S (2010). Hydrogen peroxide as sustainable fuel: electrocatalysts for production with a solar cell and decomposition with a fuel cell. Chemical communications, 46(39), 7334-7336.

Yamazaki S I, Siroma Z, Senoh H, Ioroi T, Fujiwara N \& Yasuda K (2008). A fuel cell with selective electrocatalysts using hydrogen peroxide as both an electron acceptor and a fuel. Journal of Power Sources, 178(1), 20-25.

Yan X, Xu A, Zeng L, Gao P \& Zhao T (2018). A paper-based microfluidic fuel cell with hydrogen peroxide as fuel and oxidant. Energy Technology, 6(1), 140-143.

Yang F, Cheng K, Mo Y, Yu L, Yin J, Wang G \& Cao D (2012). Direct peroxide-peroxide fuel cell-Part 1: The anode and cathode catalyst of carbon fiber cloth supported dendritic Pd. Journal of Power Sources, 217, 562-568.

Yang F, Cheng K, Liu X, Chang S, Yin J, Du C, ... \& Cao D (2012). Direct peroxide-peroxide fuel cell-Part 2: Effects of conditions on the performance. Journal of Power Sources, 217, 569-573.

Yang Y, Xue Y, Zhang H \& Chang H (2019). Flexible H2O2 microfluidic fuel cell using graphene/Prussian blue catalyst for high performance. Chemical Engineering Journal, 369, 813-817.

Ye K, Guo F, Gao Y, Zhang D, Cheng K, Zhang W, ... \& Cao D (2015). Three-dimensional carbon-and binder-free nickel nanowire arrays as a high-performance and low-cost anode for direct hydrogen peroxide fuel cell. Journal of Power Sources, 300, 147-156.

Zhang L, Zhou M, Wen D, Bai L, Lou B \& Dong S (2012). Small-size biofuel cell on paper. Biosensors and Bioelectronics, 35(1), 155-159.

Zhang Q, Yue F, Xu L, Yao C, Priestley R D \& Hou S (2019). Paper based porous graphene/single-walled carbon nanotubes supported $\mathrm{Pt}$ nanoparticles as freestanding catalyst for electro-oxidation of methanol. Applied Catalysis B: Environmental, 257, 117886. 